\title{
Erratum to: Programmed-cell-death hallmarks in incompatible pollen and papillar stigma cells of Olea europaea L. under free pollination
}

Irene Serrano $\cdot$ Salvatore Pelliccione $\cdot$

Adela Olmedilla

Published online: 27 April 2010

(C) Springer-Verlag 2010

\section{Erratum to: Plant Cell Rep}

DOI 10.1007/s00299-010-0845-5

Unfortunately, the given and family name of all the authors have been interchanged in the Original paper. The names of the authors are now corrected.

Figure 5 of the original paper has been published wrongly with a shadow over it. The correct figure is displayed here.

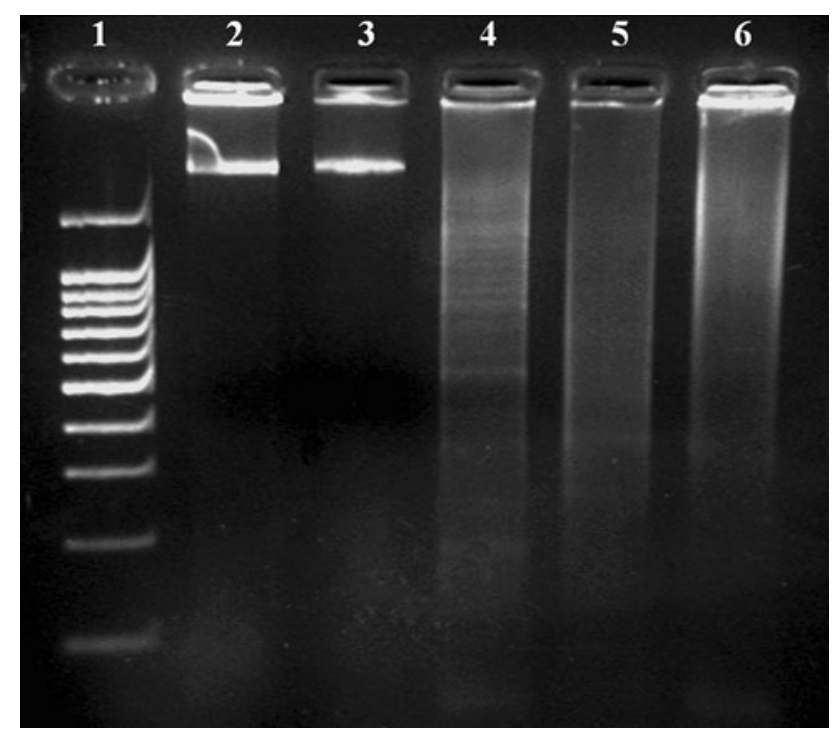

Fig. 5 Time course of DNA degradation. Lane 1 DNA marker; lanes 2 and 3 DNA from pistils excised from green flower buds and from white flower buds just before anthesis, respectively, showing no DNA degradation; lanes 4 and 5 DNA from pistils of open flowers and from flowers after petal abscission; lane 6 DNA extracted from pistils of dehiscent anthers, showing an evident DNA degradation pattern
The online version of the original article can be found under doi:10.1007/s00299-010-0845-5.

\section{Serrano $\cdot$ S. Pelliccione $\cdot$ A. Olmedilla $(\square)$}

Department of Plant Biochemistry, Cell and Molecular Biology,

Estación Experimental del Zaidín (CSIC), c/Profesor Albareda,

1, 18008 Granada, Spain

e-mail: adela.olmedilla@eez.csic.es 